British public corporations or any overseas individuals, firms or organizations are eligible to join as associate members. The Forum will be served by a secretarygeneral, who has yet to be appointed, and its offices will be at the Federation of British Industries, 21 Tothill Street, London, S.W.1.

\section{Council of Management}

The first members of the Council of Management are: H. L. Barman, Rolls-Royce and Associates, Ltd.; Dr. R. L. P. Berry, Imperial Metal Industries (Kynoch); V. F. W. Cavendish-Bentinck, Rio Tinto Zine Corporation; J. B. W. Cunningham, Dewrance and Co., Ltd.; S. A. Ghalib, the Nuclear Power Group; H. J. Grout, W. S. Atkins and Partners; Dr. J. M. Kay, Tube Investments, Ltd.; R. Y. Parry, Elliott Bros. (London), Ltd.; Col. G. W. Raby, United Power Co., Ltd.; J. S. Robertson, Babeock and Wilcox, Ltd.; A. E. Powell, Merz and MeLellan; E. C. Crossley, Lloyd's Register of Shipping; K. J. McKillop, the Water-Tube Boilermakers' Association; S. F. Steward, the British Electrical and Allied Manufacturers' Association; F. E. P. Sandilands, British Insurance (Atomic Energy) Committee; and a representative of the Law Society and of the British Medical Association; Prof. J. G. Ball; Sir Leonard Owen and Dr. D. H. Sharp of the Federation of British Industries.

\section{Electronic and Electrical Engineering at the University of Birmingham}

THe name of the department hitherto known as the Department of Electrical Engineering in the University of Birmingham has now been changed to the Department of Electronic and Electrical Engineering. When the Department was founded in 1905, electronic engineering virtually did not exist. With the development of the thermionic valve and its use first in communication systems and later in control and industrial systems and in computers, and now with the advent of numerous other electronic devices and systems, electronic engineering has become a vigorous subject advaneing at a phenomenal rate. This is reflected in the Department's present activities, which are dominantly electronic in the research and postgraduate work generally, where of the 68 postgraduate students, 60 are concerned with electronic engineering. Subjects of special prominence in the programme are radar and sonar systems, communications (electrical and acoustic), electronic circuits, ultrasonics, solid-state electronic engineering, and control systems. In the undergraduate teaching, the 'heavier' side of electrical engineering is kept in balance with electronic engineering since many of the fundamental investigations apply equally to both; but the majority of the students take electronic subjects in preference to 'heavy' subjects when options are provided.

\section{Phytoplankton Distributions South of New Zealand}

No. 7 of the Scientific Reports, Trans-Antarctic Expedition 1955-1958, provides valuable proof that the method of sampling-filtration from the ships' fire-mains, which can be done without interrupting the normal passage of a supply ship-is adequate to show up the main features of phytoplankton distribution on traverses such as that described (Distribution of Surface Phytoplankton between New Zealand and Antarctica, December 195\%. By Vivienne Cassie. Pp. $11+1$ plate. London: Trans-Antaretic Expedition Committee, 1963. 7s. net). This prompts the hope that more work will be done on the same lines. The author has justly pointed out that such data cannot be used as a basis for generalization by themselves, but only in conjunction with previous records, or similar work in the future. Seasonal succession in the plant communities concerned may be rapid, and we still do not know enough about such a major hydrological feature as the position of the Antarctic convergence, which seems exceptionally variable and ill-defined south of New Zealand. Nevertheless, several rather tentative notions derived from previous work seem to gain weight when considered along with these new observations. The convergence seems to have been farther south than usual during the traverse described here, but it is still noteworthy that ten of the commonest species in the rich mixed community to the north of it were not found farther south at that time (Fig. 2). The diatom species recorded in the extreme south (Charcotia irregularis, et al.) are typical ice-forms, capable of living on or in the packice as well as in the plankton. The wide overlap of the other dominant species in the southern half of the traverse need occasion no surprise since in one phase or another they are almost cosmopolitan. Their predominance in an exceptionally 'monotonous' type of phytoplankton community is often a feature of far southern seas, as was found during pre-war work of the Discovery investigations, since confirmed by Marumo. But this may give place to a much more varied vegetation as the season advances. The Ceratium species figured (Pl. I. Fig. $e$ ) would seem to be more like $C$. pentagonum (Gourr.) f. grandis of Mangin than C. lineatum (Ehrb.) Cleve, and the former has been found very characteristic of the convergence region, and also rarely extending south of the convergence, in other parts of the world. However, such taxonomic points cannot be definitely decided without detailed examination of several specimens.

\section{International Commission on Zoological Nomenclature}

Notice is hereby given of the possible use by the International Commission on Zoological Nomenclature of its plenary powers in connexion with the following cases, full details of which will be found in Bulletin of Zoological Nomenclature (20, Part 6; December 6, 1963): (1) Validation and emendation of, and designation of a typespecies for Stenorynchus Lamarck, 1818; validation of Inachinæ McLeay, 1838 (Crustacea, Decapoda). Z.N. (S.) 751. (2) Designation of a type-species for Chapmanina Silvestri, 1931 (Foraminifera). Z.N. (S.) 1402.

Validation of Leptocorisa Latreille, 1829 (Insecta Hemiptera). Z.N. (S.) 1589. (4) Designation of a type-species for Anolis Daudin, 1803 (Reptilia). Z.N. (S.) 1603. (5) Suppression of Naiadites elongatus Dawson, 1860, as a nomen dubium. (Lamellibranchia.) Z.N. (S.) 1604. (6) Designation of a type-species for Serpula Linnaeus, 1758, with validation of Serpula vermicularis Linnaeus, 1761 (Polychaeta). Z.N. (S.) 1606. (7) Validation of a neotype for Coenonympha ochracea Edwards, 1861 (Insecta, Lepidoptera). Z.N. (S.) 1607. Any zoologist who wishes to comment on any of the foregoing cases should do so in writing to the Secretary, International Commission on Zoological Nomenelature, c/o British Museum. (Natural History), Cromwell Road, London, S.W.7, before June 6, 1964.

\section{Design and Manufacture of Helicopter Blades}

THe design and manufacture of blades for both main and tail rotors of helicopters call for closely controlled precision processes in which a variety of woods and metals may be used. Mechanical components for these machines, in common with other aircraft, must have a high strength-to-weight ratio. Equally, fatigue loads are very high, and this factor alone demands exceptional forms of construction, especially of the rotor blades, where failure in flight can be catastrophic. In a recent issue of Ciba Technical Notes 250, an illustrated account is given of the manufacture of helicopter blades by Hordern-Richmond, Ltd., having special emphasis on the dependence of the products on certain resin adhesives, as made and supplied by the Ciba companies (Pp. 8. Duxford: Ciba (A.R.L.), Ltd., 1963). An example is quoted of a typical tail rotor blade designed for the Skeeter, the two-seater light helicopter built by Saunders-Roe Division 